Athens Journal of History - Volume 7, Issue 4, October 2021 - Pages 257-268

\title{
On Francesco Guicciardini's Thought and Some of his Considerations on Machiavelli
}

\author{
By Nicoleta Călina* E Loredana Maria Grozoiu ${ }^{ \pm}$
}

\begin{abstract}
Francesco Guicciardini (1483-1540), Italian historian, politician and writer, descendant of one of the most important and faithful families to the Medici family in Florence - received a solid humanistic education and was also the protagonist of the Italian politics in the XVIth century; during the wars between France and Spain for the domination of the peninsula, he became the fair and impartial interpreter of these events in terms of historiography. Upright and of austere character, he is the author of one of the best histories of Italy, written in the spirit of the time, whose prime quality is the historical veracity. Guicciardini fed the feeling of nationality and the aspiration to independence of Italy. In his works he shows the painful efforts of the princes and heads of republics, dragged into continuous wars, trying to defend, to confederate, to seek help in various foreign powers in order to save themselves from the oppression of the rulers. His genius, intuitive and painfully prophetic, discerns the events from the things; he pronounces what he develops as 'safe judgments' and recommends possible remedies to save the nation.
\end{abstract}

\section{Introduction}

Francesco Guicciardini (1483-1540), Italian historian, politician and writer, descendant of one of the most important and faithful families to the Medici family in Florence - received a solid humanistic education and was also the protagonist of the Italian politics in the XVIth century; during the wars between France and Spain for the domination of the peninsula, he became the fair and impartial interpreter of these events in terms of historiography.

Upright and of austere character, he is the author of one of the best histories of Italy - Storia d'Italia - The History of Italy - written in the spirit of the time, whose prime quality is the historical veracity. We must add his considerable diplomatic skills. Cavour put him ahead of Machiavelli: politician, performing many high dignities, Guicciardini is an imposing figure.

The marriage with Maria Salviati, in 1508, strengthened the political influence and it granted him the political ascension. After the war against Pisa, in 1509, he ascended very quickly in the international politics and in 1512 he was appointed by the Florentine Republic as ambassador to Spain at Ferdinand the Catholic. In 1512 he stopped writing his first work, Storie fiorentine - The Florentine Histories, to assume the diplomatic assignment that we mentioned before, the embassy to the court of Spain, where he remained until 1514. The result of this experience in his

"Associate Professor, University of Craiova, Romania.

^Researcher III, Socio-Humanistic Research Institute C. S. Nicolăescu-Plopşor, Romania. 
diplomatic activity will be the political work Il Discorso di Logrogno - The Discourse from Logrogno (1512), a proposal for a political organization of the Florentine state, within which Guicciardini sustains the reform in the aristocratic sense of the Florentine Republic.

After the moment when Giulio de' Medici became Pope Clement VII, Guicciardini is sent to govern the Romagna, a region very agitated by the struggles between the richest families. To counterpoint the power of Charles V, he proposed an alliance between the regional states of Italy and France, in order to safeguard the independence of the peninsula. The agreement was signed in Cognac in 1526, but was never put into practice. After the predation of Rome - il sacco di Roma - (1527), he was removed from the diplomatic assignments that he had been given.

In 1529 he left Florence and returned to Rome with the intention to enter the service of Pope Clement VII, and was offered the position of a diplomat to Bologna. After the fall of the Republic of Florence and restoration of the power of the Medici family, in 1531, Guicciardini returned to Florence, where he held various duties on behalf of the Medici family and Pope Clement VII, but after 1534, the new Pope Paul III didn't give him any big assignments.

After the return of the Medici family in Florence, he remained in their residence as counsellor of Duke Alessandro. In the latest years, he finished the Ricordi politici e civili ("The Political and Civil Memories"), he collected his Discorsi politici ("Political Discourses") and wrote the Storia d'Italia (History of Italy-15371540). None of Guicciardini's works was published during his lifetime.

\section{Concise Excursus Through his Most Important Works}

"The History of Italy"- Storia d'Italia begins with the history of Italy from 1490, which is the year of the death of Lorenzo the Magnificent and ends in 1534, the year of the descent into Italy of Charles VIII of France (after the predation of Rome by the Lanzichenecchi and the death of Pope Clement VII). Written by a "senior official and advisor to three popes", with ambitions of classicism - he was inspired by the "Commentaries" of Caesar -, but with a great modernity. ${ }^{1}$

Fair and impartial critic of his times, in his Storia d'Italia (History of Italy) vast and detailed image of what happened in Italy between the last decade of the Quattrocento and 1534 - he achieved excellent results as an analyst and political thinker. In Guicciardini there is a political realism that follows the idea of a unified Italian state by taking as examples the great national monarchies of Europe, but not taking into account the fact that those had been created through the strength of an enterprising and opened bourgeoisie, while in Italy a petty

1. V. De Caprariis, Francesco Guicciardini. Dalla politica alla storia (Bari, 1950), 28. 
bourgeoisie survived, unable to look beyond the narrow limits of the municipality or region.

In Discorsi politici - Political Discourses Guicciardini imitates the ancient historians, and makes them the main characters of the time. Their councils are intent to make Guicciardini's contemporaries to seek the salvation of the states which were at that time involved in the ambitions of the foreign rulers, eager to divide Italy. The Discourses have a general character because they highlight the conditions of the states of Europe and their relationships with those of the peninsula. It is part of a series of Discourses that Guicciardini wrote in 1511, after being appointed ambassador of the Republic of Florence through the Crown of Aragon, ruled at the time by Ferdinand the Catholic. This experience made him understand, in a more detached and professional way, the high-level politics of Florence, which he analyzed in his work.

Il Discorso di Logrogno ("The Discourse of Logrogno") is a juvenile political work written in 1512 in which Gucciardini sustains a reform - in the aristocratic sense - of the Florentine Republic, proposing a system similar to that of Venice. The discourse takes its name from the city where it was written, the current Logroño. In "The Discourse from Logrogno" he begins from the analysis of the various political events in Italy, still divided into regional states, to arrive at the influence on the peninsula made by the monarchical states of Europe of that time.

During the same period, Guicciardini also wrote the Relazioni di Spagna ("The Relationships of Spain") and Il Diario di Spagna ("The Diary of Spain"), and started the first draft of the Ricordi ("Memories"). His political thinking is exposed in Ricordi - "Memories" 2 and he is the author of a skeptical and disenchanted vision on politics and on the human ability to manipulate reality. "The Memories" relates to various periods of Guicciardini's activity as diplomat and politician, taking its resources from this long and complex experience. Hence the character of the work (the title really means "things to remember" and then, by extension, "thoughts", "reflections"), that faces, with a bitter and disillusioned pessimism, more general problems. These reflections can provide a useful teaching but they don't have, however, absolute validity, because reality does not obey to universal laws, maintaining a changing and unpredictable course.

Between 1516 and 1527 Guicciardini worked for the papal curia, in the service of the Medici popes: Leo X, afterwards Clement VII. In this period, he writes Dialogo del reggimento di Firenze ("The Dialogue of the Regiment of Florence") - 1521-1526, in two books. This is his only political-theoretical treaty. The work is a dialogical treaty, under the form of two days of discussion, a few weeks after the expulsion of Piero de' Medici from Florence, among people of different political views: Bernardo del Nero, a partisan of the Medici, Piero Capponi, aristocratic, Paolantonio Soderini, a partisan of the people, Piero

2. Marin Vătafu, "Antoniade, Trei Figuri Din Cinquecento," in Gând Românesc, Cluj, IV, no. 3-4 (1936): 236. 
Guicciardini, father of the writer, moderator. It is a general reflection on the state and on human nature. The author imagined a discussion held in Florence in 1494, after the death of Lorenzo the Magnificent. The interlocutors are the writer's father, Piero, Paolantonio Soderini and Piero Capponi, all Republicans, to whom Bernardo del Nero - who was linked to the Medici party - opposes. The latter, starting from a careful analysis of the facts and not from any preconceived ideas, demonstrated to the three of them how illusory their republican faith is.

Guicciardini wanted for Florence a "mixed" government, on the oligarchic Venetian example, which is superior to the defects of the signoria and of the republican regime. It comprised two magistrates formed by representatives of the wealthiest and most illustrious families, being headed by a gonfaloniere ${ }^{3}$ appointed for life. The aristocracy that Guicciardini had defended was that class of magnates, clever and intelligent people, who had been able to take control of the trade and industry, in alliance with the new mercantile and financial bourgeoisie. For him this was the only class to be skilled in the art of governing, both at the politicaladministrative and military levels. Guicciardini is a political conservative, looking with suspicion and distrust at the popular movements (e.g., Il Tumulto dei Ciompi), at the absolutism of the prince and he considers as impossible the idea of a national state.

Guicciardini realized that it was absolutely necessary to evaluate the political interference. He admitted, however, the difficulty of restoring the Medici power in that times, offering an alternative to the democratic constitution of a mixed government, which provides a gonfaloniere for life, as we mentioned, a Grand Council for the election of the magistrates, a Senate for the preparation of the laws and for the discussion of the matters of major importance. He had the belief that in politics you cannot give absolute rules, general theories or systematic doctrines valid at any time and any place. Forced to privacy for having served the Medici family, Guicciardini wrote three orations in his defense: Consolatoria, Accusatoria, Defensoria.

He composed in 1529 Considerazioni intorno ai "Discorsi" di Machiavelli sulla prima Deca di Tito Livio - "Considerations on Machiavelli's Discourses on the first decade of Titus Livius". Through a precise and rigorous analysis on the work of Machiavelli, Guicciardini tries to show that his reasoning, apparently so tight and convincing, is actually unfounded and arbitrary. The resulting worldview is so entirely relative and fragmentary, without being able to re-compound in the totality of a theoretical system capable to provide concrete and indisputable criteria. In "Considerations on the Discourses of Machiavelli", Guicciardini contested the fact that the national unification is a better goal, preferred to the balance between the various existing political entities, and sustained the fact that the autonomous development of the various cities and signorie, besides being the

3. The battle standard-bearers of the Italian republics. 
source of the economic well-being, corresponded better to the ancient customs of the Italians.

The Considerations on the Discourses of Machiavelli are the conclusion of Guicciardini's political meditation: to the deep love for the "rules" of Machiavelli, Guicciardini contraposed his empiricism, his refusal to attribute to ancient Rome a valid model for the actual reality. ${ }^{4}$

His main concern was to preserve the old municipal and corporative institutions. I Ricordi politici e civili - "The Civil and Political Memories" are more than 400 political and moral thoughts, of varying length, written between 1525 and 1530, intended to be read by family members and descendants (published, like many of his other works, only during the half of the Nineteenth century). In the Civil and political memories - Ricordi civili e politici he portrays the truest image of the society of the XVIth century, which is one fine, wise, that dazzled the world with the artistic works of universal genius, but without any faith in the state. ${ }^{5}$

Guicciardini emphasized the renascentist principle of the autonomy of the politics, totally separated from religion and morals; he claimed that history is man's product, and not of the providence, even if luck has an important place in people's lives. The persons who make history are those who have intelligence, strength, cunning, skill, authority. The historical events are indecipherable if referring to a predefined theoretical framework with which we would like to interpret them. In history, the exceptions, the fortuitous circumstances, the details, the necessary "distinguo" make impossible a general or global comprehension of reality. Facts must be understood in their particular circumstances, in each particular case.

The result of the collapse of each political illusion and of a forced renunciation of the political activism, The Memories reveal in front of the reality the disenchanted sight of the moralist. It is no coincidence that in those times when story might appeal to certain eternal principles of psychology and human behavior, the same themes and words of Memories will return. "Ricordi" ("Memories") is a large collection of scattered thoughts and notes, collected by Guicciardini. Moral and political recommendations are mixed in a work that lacks the systematic nature of the Storia d'Italia ("History of Italy"). Some of the main topics in "Memories" are: the discretion and the ingratitude (man cannot control the events, so it is impossible to give universally valid recommendations for action, to dictate general and absolutes principles). You just have to take things by each one, case by case, in their infinite nuances. The hundreds of memories provide, through the

4. Valentina Lepri and Maria Elena Severini, Viaggio e metamorfosi di un testo: I "Ricordi" di Francesco Guicciardini tra XVI e XVII secolo (Geneva: Libraire Droz, 2011), 26.

5. Enrico Zanoni, La mente di Francesco Guicciardini nelle opere politiche e storiche (Firenze: G. Barbera Editore, 1987), 11.

6. Emilio Pasquini, Introduzione ai Ricordi di Francesco Guicciardini (Milano: Garzanti Editore, 2003), 16-17. 
short and incisive form of the aphorism, suggestions for an attentive and efficient action; they valorize the practical and operational dimension of it and represent one of the first attempts at secularization of the political discourse. ${ }^{7}$

The memories were written after the retreat from the political life and all his long efforts appeared to him in the bitter light of the vanity and failure. At the end of this thought, the prevailing pessimistic tone fades into the background: the desire for honor and glory appears as an essential necessity of the human soul.

\section{On the Relationship with Machiavelli's Thought}

Guicciardini considered Machiavelli to be a "utopian" rather than a "realistic". On the theoretical side, the comparison with the positions of Machiavelli is conducted primarily in Considerazioni intorno ai Discorsi del Machiavelli sulla prima deca di Tito Livio Considerations on Machiavelli's Discourses on the First Decade of Titus Livius, written around 1529 in two books, and unfinished. They are reflections through which Guicciardini analyzes some statements or particular theoretical nuclei of Machiavelli, criticizes and deconstructs the thought of Machiavelli rather than to advance some alternative proposals or to build a different conceptual system.

Despite the common secular view, based on the "verità effettuale" ("actual reality"), Guicciardini remained anchored to an absolute and radical empiricism: he believed only in the experience and in the need to judge each case, due to the fact that each event or historical phenomenon is unique and unrepeatable and it cannot be analyzed starting from abstract and universal categories.

Although aware of the limit opposed by Fortuna to the human activity, however, Machiavelli believed in history as a rational and human construction and finds within the virtue the basis and the legitimacy of the freedoms of man and of his active and energetic capacity to build and modify the history according to his purposes and plans.

The meditation of Guicciardini began, however, from the bitter recognition of the incapacity of the individual to succeed in changing the course of the events and in reducing them to rational schemes. There is in him the consciousness of an extreme complexity and irrationality of the reality that cannot be exhausted by any formula. Therefore, it is useless to expect to establish general rules of action, because an unpredictable reality disturbs the patterns in which we would like to force it. To the virtue of Machiavelli, he shall therefore replace la discrezione (the "discretion"), which is the ability to analyze and understand the single facts in their infinite nuances, in order to insert their action in their tumultuous course,

7. Lepri and Severini, Viaggio e metamorfosi di un testo: I "Ricordi" di Francesco Guicciardini tra XVI e XVII secolo, 2011, 34. 
without being overwhelmed, while preserving its own "particularness", that is its own interest, its goals and projects.

As Machiavelli, Guicciardini believed that man is a phenomenon of nature subjected to the fixed and immutable laws, but, unlike his great friend, he believes that humans are naturally inclined to good than to wrong and if in reality he does more often bad than good, this is due to the fact that the temptations are many and the human consciousness is weak; he also belied that just doing the evil, man can more easily and more often to achieve his gain. This self-interest, which Guicciardini called "particulare" ("particular"), is actually the latch that triggers all the human actions: it most often corresponds to the material wealth, to the power, but it can also become ennobled, corresponding to the interests of the State, to the glory, to the fame.

To realize the "particular", both in a political and in a domestic way, one cannot refer to the history and draw lessons from events already occurred to resolve the facts of the present, because throughout history the events are never repeated: even when a present circumstance seems to reflect an episode from the past history, in fact the situation is quite different, as different are the persons who have to deal with it.

But if history cannot give us universal laws of behavior, our personal experience can refine in us the "discretion". And man has to follow only his relationship with the contingent reality, because the interest in wanting supernatural and invisible things it is a vain and simple mental exercise. And in respect of this consideration, he shared with Machiavelli the need to look after the "verità effettuale" ("real truth"). To the contemporary Italian situation he gave a different assessment: it was not possible for him to make from Italy at that time a unitary state, and opted instead for a confederation of small states, possibly under the form of a republic but still governed by "savi" ("wise men"). He was opposed to the temporal power of the popes (although he used it for his personal gain) and shared with Machiavelli the desire to see Italy freed from foreigners.

Significant in this regard is the following thought from Guicciardini: "I would like to see two things before I die; but I doubt that I would see it, even that I lived a lot: a life of well-ordered republic in our city, Italy liberated from all barbarians and of the tyranny of these popes."

It is no accidentally that Guicciardini made a remarkable political career. But who has been more "awarded" by the story? Which of them two could benefit from a greater historical realization of his own deals? Can we say that Guicciardini was more "realistic" than Machiavelli when he thought when Italy could oppose, only with the resources of the papacy or of a provisional league formed by the greatest Italian states, to the power of nations such as Spain or France? Was he more realistic than Machiavelli when he rejected the idea of building a non-mercenary army?

The policy of Guicciardini has been more successful than that of Machiavelli, but we cannot say that it has had more reasons. 
Before of the foreign invasions, the deliberations come first. Some decisions were not taken inside the peninsula, but at the courts of Madrid or Paris. Hence, the need to send right and able ambassadors at the foreign courts in order to learn to use a wise policy, to induce the sovereign to the wishes and views of the policies of governments they represented. Thus, in various centers of the peninsula, the loss or the preservation of the own independence, the calamities or gains that derived from the wars of Italy, depended on the ability of the ambassadors. Guicciardini outlined the specific conditions of the European powers, and calculates the hopes or the fears that they can get from them. ${ }^{8}$

The virtue that the politician must possess, for this purpose, is the discretion, which is the ability to discern with insight and based on experience, the individual events (therefore, the analysis prevails on the synthesis). In this sense, Guicciardini opposed Machiavelli; he did not accept the constant reminder of the ancients (because he thinks that past cannot help us to live the present, due to the fact that it isn't a logical sequence of historical facts), nor he appreciates the extraction of the universal laws from history. Facts cannot be traced within a unitary vision, nor can somebody pass from the particular to the general: future remains unpredictable. Hence the strong intellectual pessimism of Guicciardini, which is also manifested on the conception of man: in his opinion, human nature is fundamentally inclined to evil, at least in the moment in which someone accepts to live in society.

To this idealistic politics of Machiavelli, Guicciardini opposed a policy that he called "realistic" but that would be better described as "opportunistic"; the policy of that diplomat, who is expert in the art of negotiating and advising, very attentive to his own "particulare", that is, to his own dignity, reputation and political career. For "particulare" we must not understand the material gain.

Guicciardini divided the ambition into negative and positive. It is negative when the person who uses it in order to realize his own projects, does not scruple to trample on the basic human values (conscience, honor, humanity).

La fortuna (the luck): Guicciardini said, unlike Machiavelli, that a ruler could ascend the throne only by having la fortuna ("the luck") in his favor. La fortuna is so much more important than the virtues of each person.

The man in the social-political relationships must be able to know that: the dissimulation and the lie can serve as a useful tool to achieve their own goals. Guicciardini affirms, unlike Machiavelli, that a ruler could ascend the throne only by having the luck (la fortuna) in his favor. La fortuna (the luck) is so much more important than the virtue.

Some other Guicciardini's thoughts on the being and the appearing: the family should know how to educate their child and give him a good moral education. On the "various natures of men" Guicciardini warned on the extreme complexity of the real and on man's inability to fully control it, to impress to it the

8. Zanoni, La mente di Francesco Guicciardini nelle opere politiche e storiche, 1897, 40. 
seal of his rationality, and he also warns on the extreme precariousness of our lives. Guicciardini's analysis is not limited to the field of politics, but it covers the whole human aspects.

Having abandoned all that was absolute, Guicciardini detached himself from ideality and watched the corrupted society, but within which there still remained many good things. He researched the depths of the human heart, he studied all the social classes, he examined the various forms of government, and he expressed his opinion on each one, on its virtues and defects, trying to adapt them to the republic of Florence. ${ }^{9}$

During the sixteenth-century, Italy - as she enjoyed the triumphant splendor of the arts and philosophy and the prosperity of many cultural centers that gave birth to artists and thinkers - is attacked by the French, Germans and Swiss who want to destroy its independence. A century earlier, in the fifteenth century, the popes and the Medici family strove to end the wars, to seal treaties, to organize new leagues to maintain the balance between the Italian states. During the sixteenth century, however, each state of the peninsula searches in the confederations only its particular interest. The supreme goal of the political science in all nations is that to form the strong and independent states and to establish, with a sure criterion, the political rights of the citizens to safety and preservation of free institutions: the necessity, therefore, of the political thinker, to ponder and be precise the functions of the government and the powers of the citizens under the idea that besides the rights there are also the duties.

He noticed that the continuous changing of forms of government of Florence had diminished its prestige and studied the duties of the citizens, the fact that each class had to have its place within the social hierarchy and the limits that a well-ordered constitution had to offer to the governors and to the governed ones. According to him, the selfish and ambitious aristocracy tends to restrict the State, to exploit it only in its benefit, expelling the people from any participation in the government. ${ }^{10}$

The best government is the one, according to Guicciardini, that respects the republican appearances, as Augustus in Rome, and Lorenzo de' Medici did in Florence. Adding the minds to the virtues and to all the peculiar vices of each of the forms of government, there was the need to seek for a form that would satisfy and harmonize all the interests, to calm all the passions, to make the citizens content and happy in the enjoyment of a fair and safe freedom, away from the dangers that could come from the outside of the form of state.

Within the medieval form of states, freedom was frequently confused with the possession of power and with the proscription of the opposite party. There was not yet developed the sense of civic duty that would, in his turn, be the legal and practical basis of freedom.

9. Ibid, 10 .

10. Ibid, 19. 


\section{Conclusion}

Guicciardini fed the feeling of nationality and the aspiration to the independence of Italy. In his works he showed the painful efforts of the princes and heads of republics, dragged in continuous wars, trying to defend, to confederate, to seek help in various foreign powers in order to save themselves from the oppression of the rulers. His genius, intuitive and painfully prophetic probably discerned the events from the things, he pronounced safe judgments, and he recommends possible remedies to save the nation. He is always serene in the examination of the facts, but reveals his fears and his love for Italy, which would like free by the Spanish with the help of the French.

In his vast collection of letters there is engraved the cry of sorrow for the misfortunes that plagued the Italian states and the bitterness against the ferocity of the invaders and against the princes, captains, soldiers, unable to face the fortune and win it. His writings form one of the greatest and wise documents on the Italian states situation in the sixteenth century, serving to illuminate an entire epoch. There is a sense of nostalgia in Guicciardini for the noble and pure people; he is a powerful Florentine genius, a natural product of the times, deep, skeptical, practical and brilliant, expressing his deep observations with an elegant style.

\section{Bibliography}

De Caprariis, V. Francesco Guicciardini. Dalla Politica alla Storia, (From Politics to History.) Bari, 1950.

Lepri, Valentina and Maria Elena Severini, Viaggio e Metamorfosi di un Testo: I "Ricordi" di Francesco Guicciardini tra XVI e XVII Secolo. (The Journey and Metamorphosis of a Text: I "Ricordi" by Francesco Guicciardini Between the 16th and 17th Centuries.) Geneva: Libraire Droz, 2011.

Pasquini, E. Introduzione ai Ricordi di Francesco Guicciardini. (Introduction to Memories of Francesco Guicciardini.) Milano: Garzanti Editore, 2003.

Vătafu, M. "Antoniade, Trei Figuri Din Cinquecento." (Three Profiles from the Sixteenth Century.) Gând Românesc, Cluj, IV, no. 3-4 (1936): 36-37.

Zanoni, E. La Mente di Francesco Guicciardini nelle Opere Politiche e Storiche. (The Thought of Francesco Guicciardini in the Political and Historical Works.) Firenze: G. Barbera Editore, 1897. 


\section{Appendix 1}

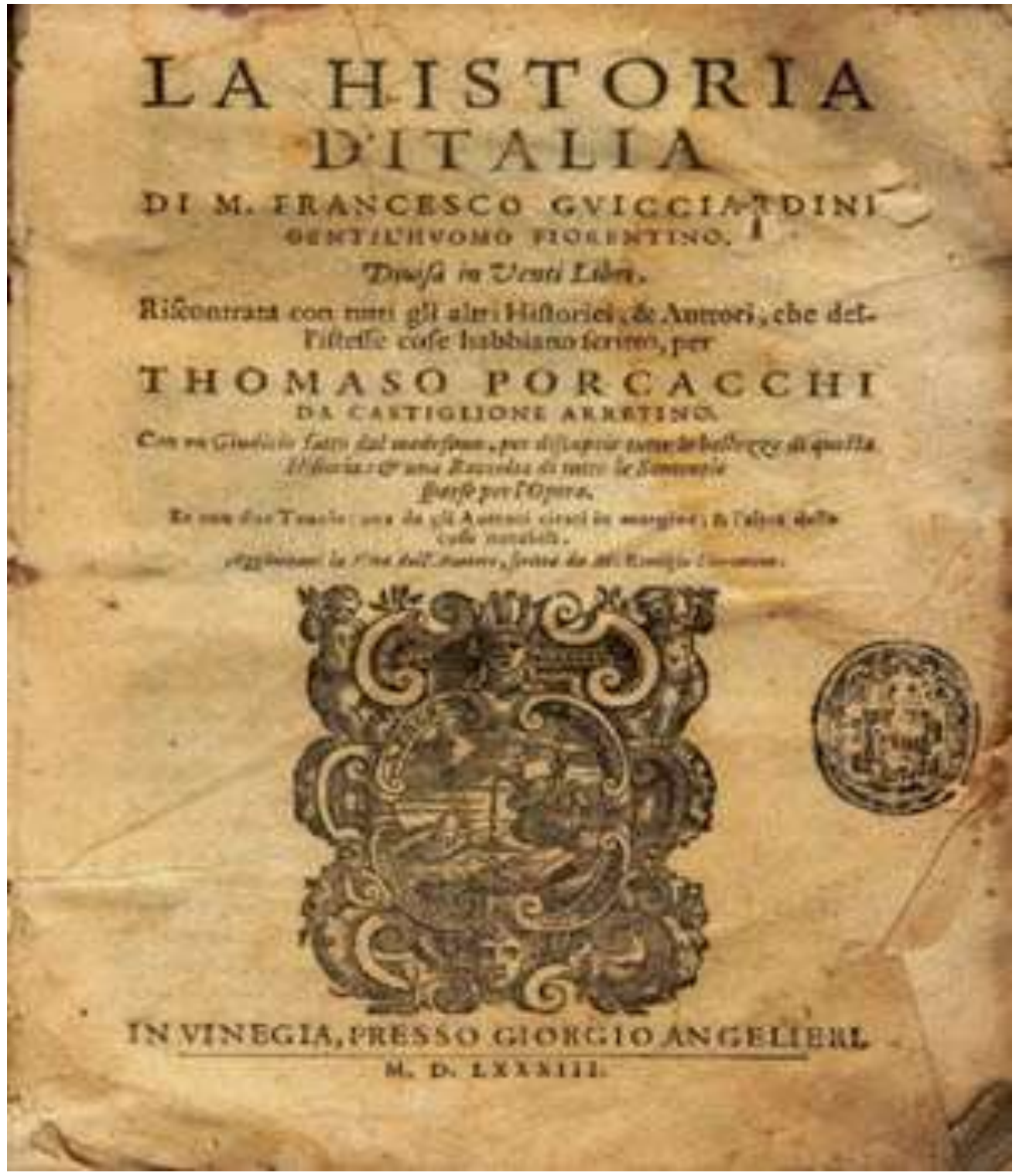


